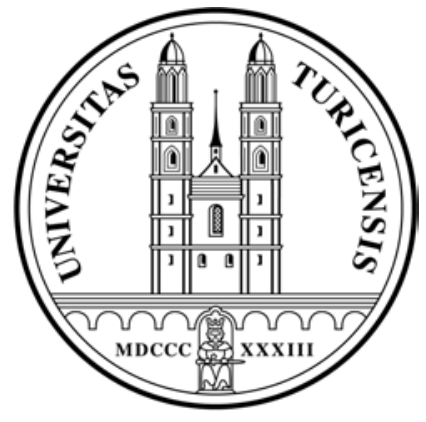

Institute for Empirical Research in Economics

University of Zurich

Working Paper Series

ISSN 1424-0459

Forthcoming in: Academy of Management Review

Working Paper No. 166

Corporate Governance:

What can we Learn From Public Governance?

Matthias Benz and Bruno S. Frey

May 2005 
Forthcoming in: Academy of Management Review

\title{
Corporate Governance:
}

\section{What Can We Learn from Public Governance?}

\author{
Matthias Benz And BRUno S. FreY*
}

(final version, May 20, 2005)

\begin{abstract}
In view of recent corporate scandals, it is argued that corporate governance can learn from public governance. Institutions devised to control and discipline the behavior of executives in the political sphere can give new insights into how to improve the governance of firms. Proposals in four specific areas are discussed: manager compensation, the division of power within firms, rules of succession in top positions, and institutionalized competition in core areas of the corporation. (73 words)
\end{abstract}

\footnotetext{
* Institute for Empirical Research in Economics, University of Zurich, Bluemlisalpstr. 10, CH-8006 Zurich, Switzerland. Tel.: +41 1634 3731. Fax: +41 1634 4907, e-mail: matbenz@iew.unizh.ch, bsfrey@iew.unizh.ch. A previous version of this paper was presented as a Keynote Lecture at the Annual Conference of the Association of German-Speaking University Teachers in Business Economics, Zurich, and at CLEF, Comparative Law and Economics Forum, University of California at Berkeley. We benefited greatly from discussions on corporate governance issues with Margit Osterloh and Reiner Eichenberger, and we are grateful for comments on earlier versions from Christoph Engel, René L. Frey, Jesse Fried, Henry Hansmann, Bernd Helmig, Dennis Mueller, Daniel Rubinfeld and Alois Stutzer. We are particularly indebted to three anonymous AMR reviewers for their helpful remarks. The paper was written while the first author was visiting the Boalt School of Law, University of California at Berkeley. He gratefully acknowledges its hospitality, as well as financial support by the Swiss National Science Foundation.
} 
The corporate world has recently experienced a sobering up. The stock market has crashed, and the corporate sector has been plagued by huge scandals relating to excessive manager compensation and fraudulent bookkeeping. There is a widespread concern that corporate governance mechanisms have failed to prevent these scandals. As a consequence, improvements in corporate governance are sought after, like those embodied in the Sarbanes-Oxley Act, and regulators are considering further changes to improve the corporate governance system.

The weaknesses and failures of actual corporate governance practice suggest that it might be useful to approach the issue from a new perspective. In this paper, it is argued that fresh insights for corporate governance can be gained from the way democratic government and public administration are organized. Corporate governance can learn from public governance, in the sense that institutions devised to control and regulate the behavior of actors in the public sphere can give new insights into how to improve the governance of firms. The public governance perspective offers a distinct set of theoretical ideas on corporate governance, it proposes governance mechanisms that differ substantially from what is currently practiced, and it advances research questions that diverge from those pursued by accepted theories.

The notion that corporate governance can learn from public governance does not mean, of course, that public governance has produced ideal results - far from it. It is well-known that democratic politics and public administration are subject to many inefficiencies and scandals, and that distortions due to rent seeking activities are prevalent. These aspects have been analyzed in depth by Public Choice Theory or Modern Political Economy. ${ }^{1}$ But this does not exclude that some

\footnotetext{
${ }^{1}$ For introductions see e.g. Frey (1978), Persson \& Tabellini (2002) and Mueller (1997, 2003). The shortcomings of public bureaucracy are discussed in Niskanen (1971) or Wintrobe (1997), and rent seeking in Tullock, Tollison \& Rowley (1988) and Tollison \& Congleton (1995).
} 
institutions of public governance may be useful for corporate governance. Neither does this exclude that public governance can learn from corporate governance, but this direction of learning has been extensively discussed in the past and has resulted, for example, in the introduction of New Public Management in at least some parts of public administration (e.g., Pollitt \& Bouckaert, 2000).

The approach followed here stands in the tradition of Constitutional Political Economy, the economic analysis of political institutions, and thus strongly resorts to theories political economists have developed on the workings of political processes (for surveys, see Frey, 1983; Mueller, 1996; Cooter 2000). In proposing the public governance approach, our primary goal is not to re-consider existing corporate governance theories, such as Agency Theory, Stewardship Theory, or Resource Dependence Theory (for reviews, see e.g. Hung, 1998; Daily, Dalton \& Cannella, 2003). Rather, our aim in this paper is to break new ground, by introducing new, forgotten or neglected aspects. As a consequence, however, the ideas for organizational design differ substantially from what is suggested by accepted theories.

We propose that corporate governance can learn from four cornerstones of public governance. First, we argue that corporate governance can gain from realigning managers' compensation with the practice prevalent in the public sector, namely fixed compensation not dependent on pay-forperformance. Second, we consider the advantages of relying on the basic democratic idea of division of power in corporate governance. Third, we discuss how rules of succession prevalent in the political sphere can be applied in order to devise better governance rules. And fourth, we propose that corporate governance can be improved by relying on institutionalized competition in core areas of the firm. In addition to the arguments advanced, we outline the differences of the 
public governance approach to other corporate governance theories with respect to their theoretical ideas and research emphases.

\section{RETURN TO FIXED COMPENSATION}

Public governance teaches us that politicians, public officials and judges receive fixed salaries, because those persons who set the regulations should not be given an incentive to manipulate the corresponding criteria in their own favor. In management, the exact opposite has taken place over the 1990's: the top executives were given the opportunity and the incentives to manipulate the criteria by which they were evaluated and compensated.

The public sector approach to pay avoids fundamental problems connected with pay-forperformance, some of them well-known in the business economics and economics literatures. Performance is rarely easily defined in the public sector, and in many cases, only some aspects of performance are measurable, leading to the multi-tasking problem that only those tasks are performed that are subject to performance pay (Holmstrom \& Milgrom, 1991; Tirole, 1994; Prendergast, 1999). In a politico-economic view, however, there are some more fundamental issues involved. Political economists have traditionally focused on politicians' possibilities and incentives to manipulate the criteria by which they are evaluated (for early applications, see e.g. Frey \& Schneider, 1978a,b; Frey, 1983). In this view, pay-for-performance for politicians and bureaucrats does not make sense, because they are the ones who decide over the very standards they are compensated by.

The public governance view suggests that corporate governance can gain from taking this insight seriously and in consequence return to more fixed forms of top-management compensation. The 
system of pay-for-performance that has built up during the 1990's has induced managers to devote time and effort to influencing their variable income. Managers rationally engage in unproductive rent seeking activities in order to manipulate the performance standards and therewith their income. While they can seek higher income by increased effort, they have often found it easier and less demanding to influence the measuring rod, even by distorting and falsifying the figures. The public governance perspective finds considerable support in the empirical literature. Several empirical studies have shown that there is a strong relationship between the extent of variable, stock-based executive compensation and the incidence of corporate fraud. It has been documented, for example, that CEOs of firms that restated their earnings in 2000 and 2001 held an average value of "in-the-money" stock options of $\$ 30.1$ million, while CEOs in a matched sample of firms without earnings restatements only held \$2.3 million (Efendi, Srivastava \& Swanson, 2004). A study of accounting frauds over the period 1996-2003 indicated that the proportion of stock-based compensation to total compensation for the five top executives was considerably higher in fraud firms than in comparable non-fraud firms, on average 56 percent vs. 41 percent (Erickson, Hanlon \& Maydew, 2003). Similarly, it has been shown that managers involved in accounting frauds over the period 1992-2001 had a 69 percent higher pay-for-performance sensitivity than managers not involved in frauds, a result of their much higher stock and stock option compensation, approximately $\$ 4.4$ million more at the median (Johnson, Ryan \& Tian, 2003). Performance pay is thus found to give executives strong incentives to engage in manipulation activities.

It is noteworthy that dominant approaches in corporate governance theory, such as Agency Theory, have to a large extent failed to see this rational reaction by managers subjected to payfor-performance, an observation that is now largely acknowledged by proponents of Agency Theory (Becht, Bolton \& Röell, 2002: 47; Jensen, Murphy \& Wruck, 2004: 98). The corporate frauds that have occurred, however, have caused enormous damage, not only for the companies, 
investors and employees involved, but arguably also for the market economy as a whole. The U.S. General Accounting Office estimates, for example, that accounting restatements over the period 1997-2001 have cost investors about \$100 billion in market capitalization losses, and have seriously damaged public confidence in the business community and capital markets (GAO, 2002: 26-41).

A system of fixed compensation, as favored in public governance, differs substantially from payfor-performance, in that it induces actors to concentrate on work content rather than on compensation. Fixed incomes have the important advantage of serving as "redistribution constraints" (Hansmann, 1996; Osterloh \& Rota, 2003; Frey \& Osterloh 2005). They free individuals from fighting over earnings and lead them to devote their effort to productive activities. As a result, rent seeking and negative sum games are reduced, and incentives to manipulate the standards of compensation are diminished.

There are several obvious counterarguments against purely fixed compensations for top managers. Most importantly, firms act in a different environment than governments and public bureaucracies, and entrepreneurial incentives are supposed to be more important on the market than in democratic decision-making. This distinction indeed has always been part of Modern Political Economy (Dahl \& Lindblom, 1953). The public governance approach should therefore not be taken to mean that managers should be badly paid, or that they should not be given any incentives at all. Public sector experience clearly shows that wages that are too low can lead to problems of their own, like an increased willingness of public officials to accept corruption payments (Rose-Ackerman, 1999; DiTella \& Schargrodsky, 2003). The public governance perspective suggests, however, that the current focus on performance pay in the private sector is 
overdrawn, and that corporate governance practice can benefit from a return to a predominantly public sector style fixed compensation.

A related counterargument against fixed compensation is that managers only work in shareholders' interests when they are given the appropriate pay-for-performance incentives. The existing evidence on management pay, however, suggests that predominantly fixed compensations can be a suitable way to remunerate top managers. Decades of research have shown that there is only a weakly positive relationship between management compensation and firm performance (Tosi, Werner, Katz \& Gomez-Mejia, 2000; Murphy, 1999: 2555-6). Research moreover suggests that the supposed positive effects of performance pay might already be achieved with a relatively low incentive intensity (Bucklin \& Dickinson, 2001). Thus, a predominantly fixed compensation with a moderate amount of performance incentives (e.g. a 20 percent share of total compensation in restricted stock) may already combine the virtues of public sector style and performance-oriented compensation. This is to contrast with the current situation, where in 2003, top managers in the United States received 67 percent of their total compensation in a stock-based form, about half of it in stock options (New York Times, 2004). The public governance perspective thus advocates a fundamental change in manager compensation. The proposed effect is a significant reduction of managers' incentives to engage in deceitful and illegal behavior, while a certain level of entrepreneurial incentives for executives is maintained in order to ensure performance.

\section{DIVISION OF POWER}

An important function of corporate governance is to control and discipline management (Daily et al., 2003). The same goal is shared by democratic government, where disciplining public agents 
is a central task. In both areas of governance, a core problem is that persons occupying leading positions tend to accumulate uncontrolled discretion. For centuries, democracies have developed various effective institutions to restrict this accumulation of power. Of paramount importance is the idea of division of power. Democratic states distribute the right to act among the three classical decision-making bodies: the executive, legislative and jurisdictive branches. Democratic constitutions actively promote the principle of checks and balances. This does not prevent one branch from dominating for a period of time, but it ensures that the other branches can reassert themselves in due time. This principle is clearly visible in, among others, the American constitution.

A close analogy has often been seen between private corporations and the public sector. The CEO corresponds to the head of government, the company board to the members of the cabinet, and shareholders are corporate citizens convening in a town council meeting. The political structures of the private and the public sector, however, also differ in fundamental respects. Most importantly, the principle of division of power is applied much less strictly in corporate governance than in public governance (Kesner \& Dalton, 1986). In many countries, in particular in the USA, France and Switzerland, it is common practice that the CEO of the firm is at the same time the chairman of the board and therewith of the shareholder meeting. This blurs the division between the top agents (CEOs) and the principals (shareholders). In the same vein, not much attention has been paid until recently to a clear separation of the control over core aspects of the firm, like the independence of compensation and audit committees.

Division of power is an area where corporate governance can gain insights from public governance, and indeed it already has to some extent. In public governance, there is an independent institution controlling the executives, the "court of accounts", "Rechnungshöfe", or, 
in the United States, the "General Accounting Office". In many countries, the competencies of courts of accounts are quite restricted, so that in Germany, for instance, the "Rechnungshöfe" may only inform the parliament and the public about the way the executive performs his or her task, but may not interfere (Frey, 1994). These courts of accounts derive their independence from being part of the jurisdictive branch. In Switzerland, in contrast, an interesting form of "Rechnungsprüfungskommissionen" exists that derives its independence from being directly elected by the citizens. Empirical evidence shows that such directly elected courts of accounts have a considerable impact on the quality of government (Schelker \& Eichenberger, 2003, 2004). It seems that they successfully restrain local governments from abusing their power, and induce them to act more strongly in the citizens' interests.

The corporate sector has often not clearly separated the executive and external auditing functions, at least until recently. In many cases, CEOs determined the auditing firms that were supposed to control them. At the same time, the auditing firms were, and still are, paid for advising jobs for the CEO and general management (Economist, 2004). As a result of the scandals produced by this system, there are now government-imposed rules in many countries, more clearly separating the executive from the auditing branch. In the US, for example, it is now required that all members of a company's audit committee are independent directors, and that the audit committee, rather than management, is directly responsible for the appointment, compensation, retention and oversight of the work of the auditors (Sarbanes-Oxley Act, see Securities and Exchange Commission, 2003a). Similar standards now also apply to the compensation committees (NYSE, 2003). This is an area where corporate governance has co-opted institutions applied in public governance, but only after having incurred huge costs. 
The public governance perspective suggests, however, that more could be learned from the public sector. The independence of the auditing process could be further improved by relying on the democratic mechanism of direct elections for (a) the members of the audit committee and (b) the auditing firm by the shareholders. This reflects the basic democratic idea that the independence of a committee ultimately has to be based on the fact that it has been freely chosen by the people who have an interest in it being independent - in this case the shareholders. The reasoning can also be applied to compensation committees and the choice of the auditing firm, whose independence would be strengthened by competitive elections. Evidence from the public sector shows that the direct election of independent bodies leads them to take the citizens' interest better into account than when they are just appointed (and are more likely to be "captured" by those they are supposed to control). It has been documented, for example, that public regulators act in a more consumer-friendly way when they are directly elected by the citizens rather than appointed by politicians (Besley \& Coate, 2003). Similarly, elected courts of accounts that are independent of local governments have been shown to improve public policies in Swiss municipalities (Schelker \& Eichenberger, 2003, 2004).

The most important area where corporate governance violates the principle of division of power is CEO duality, i.e. when the CEO of the firm is at the same time the chairman of the board. From a public governance perspective, this seriously blurs the distinction between the management and the board who is supposed to control it. In contrast to this view, however, the existing empirical evidence shows that CEO duality does neither lead to catastrophic nor to beneficial consequences. While researchers have found a weakly positive relationship between CEO duality and the incidence of corporate fraud (Erickson, Hanlon \& Maydew, 2004; Uzun, Szewczyk \& Varma, 2004; Beasley, 1996; Dechow, Sloan \& Sweene, 1996), a large number of 
empirical studies documents that firm performance is essentially unaffected by the combination of the chairman and CEO positions (Dalton, Daily, Ellstrand \& Johnson, 1998). According to this evidence, one might conclude that the public governance approach overstates the importance of division of power in firms.

From a public governance perspective, however, the existing empirical literature has taken a relatively simplistic view on CEO duality. Independence of the two positions is simply assumed as given if they are held by different persons (Dalton et al., 1998: 271-272; Daily \& Dalton, 1997). A closer look at split chairman / CEO roles in S\&P 500 firms, however, reveals a strikingly different nature of these arrangements. In 2004, out of 112 chairman positions held separately (i.e. not by the current CEO), 63.4 percent (71) were occupied by the former CEO of the firm, 14.3 percent (16) by a former or current executive of the firm, and only 22.3 percent (25) by a truly independent person (The Corporate Library, 2004; see also Vancil, 1987). This evidence seriously questions whether split chairman / CEO positions can in practice be considered as an effective control device, given, among other factors, the important role that outgoing CEOs play in the determination of their successors (Shen \& Cannella, 2002) and the fact that current executives are supposed to monitor their own bosses. The public governance perspective offers in this instance novel insights with respect to scientific inferences as well as corporate governance practice.

With regard to scientific inferences, the public governance view suggests a novel theoretical relationship that future empirical work can test: the beneficial effects of division of power on organizational outcomes are expected to be the larger, the greater is the actual independence of the chairman vis-à-vis the CEO. It can be hypothesized that actual independence increases in the relational distance between the two persons: it is highest for truly independent chairmen (who are 
not a former CEO nor a current or former executive), followed by former CEOs or executives, current executives, and at the low end, CEO/chairman positions held by the same person. Empirical research might also test several interesting interaction effects that can be related to the diverse nature of split CEO/chairman positions. For example, one might consider differential implications of having a former CEO as chairman and an outsider/insider CEO as his successor, where independence is supposed to be higher in the "former CEO/outsider CEO" case (Shen \& Cannella, 2002), or interaction effects with the issue of split CEO/COO appointments can be explored (Hambrick \& Canella, 2004). In any event, the public governance perspective suggests a more thorough view on the actual division of power in top positions of corporations.

The public governance approach also has implications for corporate governance practice. Given that its strong emphasis on division of power is correct, it follows that the positions of chairman and CEO should be separated, and the former filled with truly independent persons. Preferably, this could be done in competitive elections, where the chairman is directly elected by the shareholders. In a related manner, the public governance approach may offer a new rationale for why shareholder activism in the U.S. has generally aimed at a separation of the chairman/CEO functions, despite the apparently non-existing effects on company performance (Daily et al., 2003: 373), and for why reform proposals in countries like Germany or the United Kingdom require or at least recommend a separation of the CEO and the chairman of the board positions (Hopt \& Leyens 2004). 


\section{RULES OF SUCCESSION}

Democratic constitutions constrain their agents not only by division of power, but also by extensive rules of law that regulate the succession and the rotation in leading positions. Three rules are of particular importance:

(a) Restricted terms of office. The members of parliament and directly elected presidents are (normally) elected for four years. At the end of this period, their term in office ends automatically; no further decision is needed.

(b) Reelection restrictions. Many constitutions know the provision that a president may only be reelected for one additional term. This is a very strong constraint: it can safely be assumed that many, if not most, presidents would have been reelected for more terms. In some Swiss cantons (e.g. in Basel-Stadt), popular initiatives have successfully restrained the number of terms in office of the members of parliament. The German Green party introduced similar provisions, but they have since been mitigated or totally abolished.

(c) Rotation of positions. Some parties (again the German Green party is an example) instituted an automatic change of positions between the leaders of the party and the party's representatives in parliament or government. The Swiss government rotates the position of the president of the Federal Council every year among the seven council members.

The basic idea behind these rules is that they are able to effectively restrict the power of public agents. Moreover, they also open positions to newcomers, and therefore to fresh ideas. Of the three rules, the one relating to restricted terms in office is the most commonly used in public governance, being part of essentially all existing democratic constitutions. But also the 
requirement of reelection restrictions is common, most notably in the form of the two-term limit for the US president.

Corporate governance also knows either self-imposed or government-imposed rules, but they are much less far reaching than those used in public governance, mainly because the market is supposed to control firms. In principle, the terms of office of agents in private corporations are limited, even more so than in public governance. In the United States, for example, the members of the board have to stand for reelection every year at the shareholder meeting (Bebchuk, Coates \& Subramanian, 2002). But in practice, this is just a formal provision of no real consequence. Recent empirical evidence indicates that board seats have almost never been contested in the U.S. from 1996 to 2002, which means that automatic reelection is the rule (Bebchuk, 2003). ${ }^{2}$ For top managers, there are no formal term limits, as they are subject to a standard employment contract and can be dismissed at any time by the board.

Corporate governance can learn from public governance by considering formal term limits for top agents. The main advantage of term limits is that they entail an automatic end of office, where no further discussion and decision is needed, and that they bring about a binding reelection constraint. In the case of board members, such a regime would basically reinstall the idea lying behind existing laws. In practice, however, it would certainly lead to major changes, like the emergence of genuine competitive elections for board positions. Term limits can also be envisaged for the top executive function of the CEO, for example in the form of a two or four

\footnotetext{
${ }^{2}$ Bebchuk (2003) gives several reasons why board seats are almost never contested. Although shareholders can in principle nominate director candidates, they can do so only by soliciting separate corporate proxies. The costs and difficulties of running such proxy contests are high, and their attractiveness is further hampered by a public good problem (the soliciting shareholders bear all the costs, but only reap a fraction of the benefits). Moreover, many boards in the US are "staggered", i.e. only a fraction of board members stands for reelection every year.
} 
year term. Naturally, such term limits for CEOs would entail advantages as well as some disadvantages.

With respect to disadvantages, the discussion can be informed by the existing public governance literature. It is a well-established fact in political economics that four-year term limits for politicians lead to certain dysfunctionalities. In particular, politicians tend to create "political business cycles" around election dates. In order to create a favorable state of the economy (which is positively evaluated by voters), they influence economic variables like unemployment and inflation, with real costs accruing after the election, or they target public projects in order to win the support of important interest groups (for a survey, see Frey \& Benz, 2003). The same reasoning can be applied to the corporate sector: four-year term limits would lead CEOs to manipulate company fundamentals such that the firm can be presented in a favorable light at reelection time.

The dysfunctional effects of term limits, however, have to be evaluated in a comparative perspective. The current pay-for-performance systems arguably give CEOs incentives to act in an even more short-sighted way, as the recent corporate scandals have made clear. Seen from this perspective, well-defined term lengths of four years have several advantages. First, term limits always contain an element of term "guarantee" - they reinstall an incentive to develop a longterm view on business, as CEOs are basically granted a four-year period to achieve their goals. If CEOs perform well, they can be confident to be reelected for a second or subsequent terms, based on a long-term assessment of their performance. Second, the increased job security leads top managers to invest more in firm-specific human capital, which cannot be sold to other firms and thus benefits shareholders (Harris, 1990). And third, term-limits create strong incentives for the persons electing a CEO to carefully choose a top manager. 
Term-limits thus need not be an alien element in the corporate world. They have a public sector element, by freeing CEOs from excessive short-term pressures, but at the same time they introduce a control device currently completely absent form the corporate sector. Binding reelection constraints can meaningfully complement the control that CEOs face from the product and financial markets. Moreover, they can (but need not necessarily be) combined with the requirement of a maximum number of possible reelections. Well-known private firms such as McKinsey, a consulting partnership, enforce term limits of three years for their managing director and combine them with a reelection restriction of a maximum of three terms (New York Times, 2003). In contrast, while all political constitutions know term limits of typically four years, reelection restrictions are rather the exception than the rule (they often exist for heads of state like the U.S. president, but are less common for members of parliament like the U.S. Senate or Congress).

\section{INSTITUTIONALIZED COMPETITION}

The probably most important area where corporate governance can learn from public governance is from the latter's strong emphasis on institutionalized competition. Democratic governance can be understood to be the competition by parties for votes (Schumpeter, 1942; Downs, 1957). This competition is closely regulated, but it is fundamentally an open competition. There are three main features:

(a) Voting rights. Only citizens may participate, and each citizen has one vote. Elections are individually oriented as the voters can determine which persons will sit in parliament. In some 
cases (especially at the local and provincial level), the voters are able to also choose the persons in the executive branch.

(b) Competitive process. Elections must be open and the citizens must have a choice between several different options, i.e. parties and persons.

(c) Voting rules. Various mechanisms for aggregating votes are used, the best known being "first past the post" leading to strong majorities, but tending to exclude minorities (the system used in the United States and United Kingdom), and the proportional system (used in most European countries). The latter sometimes guarantees seats for minorities, or excludes parties with less than a certain percentage of votes (e.g. $5 \%$ in Germany).

There are several similarities between the voting and representation processes used in the public sector and in stock companies. In both spheres there is a collective action problem related to dispersed "ownership". Corporations use elections by shareholders to determine the members of the board, and the board then elects the top management and the external auditing firm. But there is a fundamental difference in the election process, as we know it, that distinguishes the corporate sector from the public sphere: in most corporations, there is generally no choice between various alternatives. As a matter of course, the shareholders are offered one person to be elected for one position on the board, and only one external auditing firm can be chosen, and the CEO cannot be chosen at all.

We suggest that corporate governance can learn from public governance with respect to the following three aspects: voting rights, competitive election processes, and voting rules. 


\section{Voting Rights}

In principle, each share has one vote. However, this principle is often violated by privileged shares or by non-voting shares. Such devices are often used to prevent unfriendly takeovers (Seligman, 1986; Grossman \& Hart, 1988), and they are used in many countries (Economist, 2005). Their abolishment would strengthen corporate control and secure truly "democratic" shareholder representation.

Voting rights may in principle also be given to non-shareholder groups, like the employees. A regime of "co-determination" can be seen as a formal recognition of "corporate citizenship" or, more broadly, of "organizational citizenship". The German experience with co-determination shows that giving employees representation rights does in general neither hurt nor improve firm performance (Addison, Schnabel \& Wagner, 2004). However, it has been stressed in the literature that the beneficial effects of employee participation are likely to be restricted to firms with much firm specific human capital (Furubotn, 1988; Roberts \& Van den Steen, 2000; Osterloh \& Frey, 2005). To the extent that employees' firm specific human capital becomes more important in the "knowledge economy", corporations may develop an increasing interest in the experience many European countries have made with co-determination.

\section{Competitive Process}

Democracy is not well developed within corporations. The essential element of competition, namely that the voters can choose between relevant alternatives, hardly exists. For instance, for a truly democratic process, the persons with voting rights in the firm must have the option to choose between various persons willing to serve as directors. Similarly, they must be able to 
choose between several competing firms offering external auditing. In both cases, the competitors must be willing to clearly state their interests and program, and must be able to convince the corporate voters that they are capable of fulfilling the required tasks. It is difficult to see why such a competitive process exists in the political sphere, but is often taken to be impossible within corporations. Paradoxically, the way in which capitalist corporations today select their most important representatives reminds of former communist, undemocratic regimes: there is one option to choose from, and it gets chosen with a huge majority.

Corporate governance can learn from public governance by rediscovering the importance and the power of institutionalized competition. Competitive elections seem obvious at the very least for positions on the board. Board members are the representatives of shareholders, and it is hardly conceivable why shareholders should not have the possibility to exercise their right of free choice (see also Bebchuk, 2003, 2004). It is a simple but powerful public governance point that good representation can only be secured if voters have the opportunity to freely choose their representatives. This insight, however, seems to have become completely forgotten in corporate governance.

Competitive elections may not only apply to board members, but can be further extended to core areas of the firm. For example, a strengthening of corporate governance can be expected if shareholders are given the right to determine the board members that specifically sit on the auditing and the compensation committees, and to elect between different auditing firms. Such elections would greatly improve the independence of the respective actors. It vests them with a unique, institutionally based legitimacy to take an independent stance. At the same time, it secures their accountability to shareholders in important corporate matters. 
To see the potential of competitive elections for corporations, one may even go a step further. Instead of the board members being faced with a choice of top managers chosen by the former CEO and possibly a small group of directors aided by headhunters, the selection of a new CEO could be made in an open competition. Even more extreme, the whole management group may be opened to competition by individuals or firms prepared to fill certain positions like the CEO. The electoral competition then serves to select the most efficient group (it may be the former managers), i.e. the group the corporate voters believe to be the most capable relative to the compensation demanded. Naturally, such a far-reaching proposal raises diverse issues, like the problem of a reduced confidentially in the application process, but this should not distract from the potential value the idea has for corporations.

A main counterargument against competitive elections in corporations, in particular for board positions, is that outside directors would be amateurs relative to the managers they are supposed to control. As a consequence of this strongly asymmetric state of information, corporate governance could actually suffer from introducing institutionalized competition. It should be stressed, however, that competitive elections do not automatically mean that a larger share of outside directors is elected. Essentially, the proposal only states that shareholders should be given the possibility to choose among alternatives. It does not prescribe what kind of directors shareholders ought to elect. If the current board is perceived to perform well, it can be expected to prevail in a competitive election, whether it consists of inside or outside directors. What is important is the credible threat of non-election that institutionalized competition entails.

Although there is hardly any experience with competitive elections in public corporations, some limited related evidence exists in other organizational contexts. It has been empirically documented, for example, that electoral competition in unions leads in general to a better 
functioning of these bodies (Lipset, Trow \& Coleman, 1956; Donaldson \& Warner, 1974; Fiorito, Jarley \& Delaney, 1995). In the future, the presumed effects of competitive elections in corporations might be empirically investigated if a proposal by the SEC is introduced, requesting that shareholders should have the right to nominate two directors of their choice in the company's proxy material (Securities and Exchange Commission, 2003b). Although this proposal is much less far reaching than what is advanced here, it might serve as a first empirical test of the consequences that electoral competition has for the functioning of firms.

\section{Voting Rules}

Public governance tends to be rather conservative. It is difficult to extend the area of democratic participation or to introduce new voting rules. The major reason is that the established politicians, parties and interest groups fear to lose from such changes. The corporate sector, being more dynamic than the public sector, should find it easier to consider new voting mechanisms for shareholder votes or for decision taken by the board. Examples are voting by veto (Mueller, 1978) or storable votes (Casella, 2002), but there are many others. Firms can choose the respective innovative voting rules where they are most appropriate, while sticking to simple majority, qualified majority or unanimity elsewhere.

In sum, institutional devices characteristic for public governance, like broad representation practices, competitive elections and innovative voting rules, can serve as a pool of ideas and novel approaches to improve corporate governance. Most notably, corporations can gain from rediscovering the power of institutionalized competition in determining their most important representatives. 


\section{DIFFERENCES TO OTHER CORPORATE GOVERNANCE THEORIES}

The public governance approach differs in its ideas and research implications from other corporate governance theories. This applies, first, to Agency Theory, which is without doubt the dominant approach used in corporate governance research (Daily et al., 2003: 371). Agency Theory is essentially a control-based theory, arguing that corporate governance mechanisms ought to be designed such that managerial self-interest is contained and disciplined (Jensen \& Meckling, 1976). The public governance approach is similar to Agency Theory in that it stresses the need to find ways to control self-interested behavior by managers. With respect to concrete governance mechanisms, however, the theoretical views and research implications differ substantially.

The distinctive feature of the public governance perspective may be summarized in one fundamental question. It asks: "who has the actual rights to decide over what?" This is a question that Agency Theory has taken rather lightly, but is at the center of public governance analysis. For example, with respect to executive compensation, we have argued that Agency Theory has overlooked the strong incentives that pay-for-performance plans have created for managers to engage in deceitful and illegal activities (Becht et al., 2002: 47; Jensen et al., 2004: 98). The public governance view, in contrast, has traditionally focused on the possibilities and incentives of those in power positions to manipulate the standards by which they are evaluated. With respect to division of power, we have shown that analyses based on Agency Theory have taken a relatively simplistic view on the question of CEO duality, simply assuming independence of chairman and CEO positions when they are held by two different persons, whereas the public governance view suggests a much closer look at the actual incentives of presumably independent chairmen to take truly independent decisions. Lastly, issues of institutionalized competition 
within corporations, like competitive elections for positions on the board, have hardly received attention in Agency Theory, while the public governance view stresses that voting rights can only deploy their controlling power if shareholders actually have different alternatives and options to choose from.

Similar points can be made with respect to Stewardship Theory, an important alternative theory to Agency Theory (Davis, Schoorman \& Donaldson, 1997). Stewardship Theory argues that managers are not so much motivated by self-interest, but are often willing to voluntarily act in the organizations' interest. The theoretical differences to the public governance approach are in this instance certainly more pronounced, because the public governance perspective to a large extent shares the view that managers have to be controlled and disciplined by appropriate governance mechanisms. A case in point is again CEO duality, where Stewardship Theory points to potential benefits of combined CEO/chairman positions (Donaldson \& Davis, 1991), whereas the public governance approach emphasizes the need to have truly independent chairmen, and advocates to more carefully study the consequences of existing split CEO/chairman roles. The public governance perspective, however, also contains elements similar to Stewardship Theory, by acknowledging that institutions can instill intrinsically motivated behavior in individuals (for the political sphere, see Frey, 1997). We have argued, for example, that competitive elections for board positions vests individuals with a unique, institutionally based legitimacy that can lead to higher pro-organizational behavior than under the present rule of quasi-appointment. In the same vein, the proposal of term limits for CEOs contains a stewardship element, arguing that it leads CEOs to take on a more pro-organizational, long-term view of business. 


\section{CONCLUSIONS}

Corporate governance can learn from public governance in the areas of manager compensation, the division of power within firms, rules of succession in top positions, and institutionalized competition in core areas of governance. The public governance view offers a novel view on the topical issue of corporate governance, it has implications for empirical research on how different governance mechanisms affect organizational outcomes, and, most importantly, it offers a distinct set of ideas for how corporate governance can be improved in practice. We hope that the new direction of learning proposed proves to be fruitful, by advancing our understanding of how corporations are governed, and by affecting the actual practice of corporate governance. The arguments have been mainly developed with respect to the classical private corporation, but to an even larger extent, they could be applied to not-for-profit firms and firms with a varying degree of governmental influence, which may substantially benefit from institutions derived from public governance. 


\section{REFERENCES}

Addison, J. T., Schnabel, C., \& Wagner, J. 2004. The Course of Research into the Economic Consequences of German Work Councils. British Journal of Industrial Relations, 42: 255281.

Beasley, M. S. 1996. An Empirical Analysis of the Relation Between the Board of Director Composition and Financial Statement Fraud. The Accounting Review, 71: 443-465.

Bebchuk, L. A. 2003. The Case for Shareholder Access to the Ballot. The Business Lawyer, 59: 43-66.

Bebchuk, L. A. 2004. The Case for Empowering Sharholders. Working Paper, Harvard Law School.

Bebchuk, L. A., Coates, J., \& Subramanian, G. 2002. The Powerful Antitakeover Force of Staggered Boards: Theory, Evidence \& Policy. Stanford Law Review, 54: 887-951.

Becht, M., Bolton, P., \& Röell, A. 2002. Corporate Governance and Corporate Control. ECGI Working Paper Series in Finance 02/2002.

Besley, T., \& Coate, S. 2003. Elected versus Appointed Regulators: Theory and Evidence. Journal of the European Economic Association, 1: 1176-1205.

Bucklin, B. R., \& Dickinson, A. M. 2001. Individual Monetary Incentives: A Review of Different Types of Arrangements Between Performance and Pay. Journal of Organizational Behavior Management, 21(3): 45-137.

Casella, A. 2002. Storable Votes. NBER Working Paper No. 9189.

Cooter, R. D. 2000. The Strategic Constitution. Princeton: Princeton University Press.

Dahl, R. A., \& Lindblom, C. L. 1953. Politics, Economics and Welfare. New York: Harper.

Daily, C. M., \& Dalton, D. R. 1997. Separate, But Not Independent: Board Leadership Structure in Large Corporations. Corporate Governance, 5(3): 126-136.

Daily, C. M., Dalton, D. R., \& Cannella, A. A. 2003. Corporate Governance: Decades of Dialogue and Data. Academy of Management Review, 28: 371-382.

Dalton, D. R., Daily, C. M., Ellstrand, A. E., \& Johnson, J. L. 1998. Meta-Analytic Reviews of Board Composition, Leadership Structure, and Financial Performance. Strategic Management Journal, 19: 269-290.

Davis, J. H., Schoorman, F. D., \& Donaldson, L. 1997. Toward a Stewardship Theory of Management. Academy of Management Review, 22: 20-47.

Dechow, P. M., Sloan, R. G., \& Sweene, A. P. 1996. Causes and Consequences of Earnings Manipulation: An Analysis of Firms Subject to Enforcement Actions by the SEC. Contemporary Accounting Research, 13: 1-36.

DiTella, R., \& Schargrodsky, E. 2003. The Role of Wages and Auditing during a Crackdown on Corruption in the City of Buenos Aires. Journal of Law and Economics, 46: 269-290.

Donaldson, L., \& Davis, J. H. 1991. Stewardship Theory or Agency Theory: CEO Governance and Shareholder Returns. Australian Journal of Management, 16: 49-64. 
Donaldson, L., \& Warner, M. 1974. Bureaucratic and Electoral Control in Occupational Interest Associations. Sociology, 8: 47-57.

Downs, A. 1957. An Economic Theory of Democracy. New York: Harper and Row.

Economist. 2004. Half measures: the auditing industry sill needs more reform. Vol. 373(8402), November 20, 2004: 16.

Economist. 2005. What shareholder democracy? Vol. 374(8419), March 26, 2005: 60.

Efendi, J., Srivastava, A., \& Swanson, E. P. 2004. Why Do Corporate Managers Misstate Financial Statements? The Role of Option Compensation, Corporate Governance, and Other Factors. Working Paper, Texas A\&M University.

Erickson, M., Hanlon, M., \& Maydew, E. 2003. Is There a Link Between Executive Compensation and Accounting Fraud? Working Paper, Graduate School of Business, University of Chicago.

Fiorito, J., Jarley, P., \& Delaney, J. T. 1995. National Union Effectiveness in Organizing: Measures and Influences. Industrial and Labor Relations Review, 48: 613-635.

Frey, B. S. 1978. Modern Political Economy. Oxford: Blackwell.

Frey, B. S. 1983. Democratic Economic Policy. Oxford: Blackwell.

Frey, B. S. 1994. Supreme Auditing Institutions: A Politico-Economic Analysis. European Journal of Law and Economics, 1: 169-176.

Frey, B. S. 1997. A Constitution for Knaves Crowds Out Civic Virtues. Economic Journal, 107: 1043-1053.

Frey, B. S., \& Benz, M. 2003. Business Cycles: Political Business Cycle Approach. In H. Vane \& B. Snowdown (Eds.). An Encyclopaedia of Macroeconomics: 89-92. Cheltenham: Edward Elgar.

Frey, B. S. \& Osterloh, M. 2005. Yes, Managers Should Be Paid Like Bureaucrats. Journal of Management Inquiry, 14: 96-112.

Frey, B. S., \& Schneider, F. 1978a. An Empirical Study of Politico-Economic Interaction in the United States. Review of Economics and Statistics, 60(2): 174-83.

Frey, B. S., \& Schneider, F. 1978b. A Politico-Economic Model of the United Kingdom. Economic Journal, 88: 243-53.

Furubotn, E. G. 1988. Co-determination and the Modern Theory of the Firm: A Property-Rights Analysis. Journal of Business, 61: 165-181.

U.S. General Accounting Office (GAO). 2002. Financial Statements Restatement: Trends, Market Impacts, Regulatory Responses and Remaining Challenges. Report 03-138. Washington. D.C.: Government Printing Office.

Grossman, S. J., \& Hart, O. D. 1988. One Share/One Vote and the Market for Corporate Control. Journal of Financial Economics, 20: 175-202.

Hambrick, D. C., \& Canella, A. A. 2004. CEOs Who Have COOs: Contingency Analysis of an Unexplored Structural Form. Strategic Management Journal, 25: 959-979. 
Hansmann, H. 1996. The Ownership of Enterprise. Cambridge, MA: Belknap Press of Harvard University Press.

Harris, E. G. 1990. Anti-Takeover Measures, Golden Parachutes, and Target Firm Shareholder Welfare. RAND Journal of Economics, 21: 614-625.

Holmstrom, B., \& Milgrom, P. 1991. Multi-Task Principal Agent Analyses: Incentive Contracts, Asset Ownership and Job Design. Journal of Law, Economics and Organizations, 7: 24-52.

Hopt, K. J., \& Leyens, P. C. 2004. Board Models in Europe. Recent Developments of Internal Corporate Governance Structures in Germany, the United Kingdom, France, and Italy. ECGI Law Working Paper No. 18/2004.

Hung, H. 1998. A Typology of the Theories of the Roles of Governing Boards. Corporate Governance: An International Review, 6: 101-111.

Jensen, M. C., \& Meckling, W. H. 1976. Theory of the Firm: Managerial Behavior, Agency Costs and Ownership Structure. Journal of Financial Economics, 3: 305-60.

Jensen, M. C., Murphy, K. J., \& Wruck, E. G. 2004. Remuneration: Where We've Been, How We Got to Here, What Are the Problems, and How to Fix Them. ECGI Finance Working Paper No. 44/2004.

Johnson, S., Ryan, H., \& Tian, Y. 2003. Executive Compensation and Corporate Fraud. Working Paper, Louisiana State University.

Kesner, I. F., \& Dalton, D. R. 1986. Boards of Directors and the Checks and (Im)Balances of Corporate Governance. Business Horizons, 29(5): 17-23.

Lipset, S. M., Trow, M. A., \& Coleman, J. S. 1956. Union Democracy: The Internal Politics of the International Typographical Union. Glencoe, Ill.: Free Press.

Mueller, D. C. 1978. Voting by Veto. Journal of Public Economics, 10: 57-75.

Mueller, D. C. 1996. Constitutional Democracy. Oxford: Oxford University Press.

Mueller, D. C. (Ed.) 1997. Perspectives on Public Choice. Cambridge: Cambridge University Press.

Mueller, D. C. 2003. Public Choice III. Cambridge: Cambridge University Press.

Murphy, K. J. 1999. Executive Compensation. In O. Ashenfelter \& D. Card (Eds.). Handbook of Labor Economics: 2485-2563. Amsterdam: Elsevier.

New York Times. 2003. British Manager Is Chosen To Lead Consulting Firm. The New York Times, March 7, 2003, Section C, p. 2.

New York Times. 2004. Executive Pay: A Special Report; Is C.E.O. Pay Up or Down? Both. The New York Times, April 4, 2004, Section 3, p. 1.

Niskanen, W. A. 1971. Bureaucracy and Representative Government. Chicago and New York: Aldine Atherton.

NYSE. 2003. SR-NYSE-2002-33 - Final NYSE Corporate Governance Rules, as of November 4, 2003. http://www.nyse.com/pdfs/finalcorpgovrules.pdf

Osterloh, M., \& Frey, B. S. 2005. Shareholders Should Welcome Employees as Directors. Working Paper, Institute for Organization and Theories of the Firm, University of Zurich. 
Osterloh, M. \& Rota, S. 2003. Open Source Software: New Rules for the Market Economy? Working Paper, Institute for Organization and Administrative Science, University of Zurich.

Persson, T., \& Tabellini, G. 2002. Political Economics: Explaining Economic Policy. Cambridge, MA: MIT Press.

Pollitt, C., \& Bouckaert, G. 2000. Public Management Reform: A Comparative Analysis. Oxford: Oxford University Press.

Prendergast, C. 1999. The Provision of Incentives in Firms. Journal of Economic Literature, 37: 7-63.

Roberts, J., \& Van den Steen, E. 2000. Shareholder Interests, Human Capital Investments and Corporate Governance. Stanford University, Graduate School of Business Working Paper No. 1631.

Rose-Ackerman, S. 1999. Corruption and Government: Causes, Consequences, and Reform. Cambridge: Cambridge University Press.

Schelker, M. \& Eichenberger, R. 2003. Starke Rechnungsprüfungskommissionen: Wichtiger als direkte Demokratie und Föderalismus? Ein erster Blick auf die Daten. Swiss Journal of Economics and Statistics, 139: 351-373.

Schelker, M., \& Eichenberger, R. 2004. Independent and Competing Institutions: An Effective Way to Control Government. Working Paper, University of Fribourg.

Schumpeter, J. A. 1942. Capitalism, Socialism and Democracy. 1st edn., New York: Harper.

Securities and Exchange Commission. 2003a. Final Rule on Standards Relating to Listed Company Audit Commitees. http://www.sec.gov/rules/final/33-8220.htm.

Securities and Exchange Commission. 2003b. Review of the Proxy Process Regarding the Nomination and Election of Directors. Staff Report, Division of Corporation Finance, July 15, 2003.

Seligman, J. 1986. Equal Protection in Shareholder Voting Rights: The One-Share-One-Vote Controversy. George Washington Law Review, 54: 687-724.

Shen, W., \& Cannella, A. A. 2002. Revisiting the Performance Consequences of CEO Succession: The Impacts of Successor Type, Postsuccession Senior Executive Turnover, and Departing CEO Tenure. Academy of Management Journal, 45: 717-733.

The Corporate Library. 2004. Split CEO / Chairman Roles - March, 2004. http://www.thecorporatelibrary.com/Governance-Research/spotlight-

topics/spotlight/boardsanddirectors/SplitChairs2004.html (as of April 2005).

Tirole, J. 1994. The Internal Organization of Government. Oxford Economic Papers, 46: 1-29.

Tollison, R. D., \& Congleton, R. (Eds.) 1995. The Economic Analysis of Rent Seeking. Aldershot: Edward Elgar.

Tosi, H. L., Werner, S., Katz, J. P., \& Gomez-Mejia, L. R. 2000. How much does Performance Matter? A Meta Analysis of CEO Pay Studies. Journal of Management, 26: 301-339.

Tullock, G., Tollison, R. D., \& Rowley, C. K. (Eds.) 1988. The Political Economy of Rent Seeking. Boston: Kluwer. 
Uzun, H., Szewczyk, S. H., \& Varma, R. 2004. Board Composition and Corporate Fraud. Financial Analysts Journal, 60(3): 33-44.

Vancil, R. F. 1987. Passing the Baton: Managing the Process of CEO Succession. Boston, MA.: Harvard Business School Press.

Wintrobe, R. 1997. Modern Bureaucratic Theory. In D. Mueller (Ed.). Perspectives in Public

Choice: A Handbook: 429-454. Cambridge: Cambridge University Press. 